\title{
Gifts for the University of Cambridge.
}

THE Vice-Chancellor of the University of Cambridge has announced that in answer to the University's application, a formal letter of gift is being prepared by the International Education Board, offering $£ 700,000$ to the University on the conditions and for the objects already announced (NaTuRE, Oct. 20, p. 632). One condition is the raising by the University from other sources of a sum of $£ 229,000$, and the Vice-Chancellor is able to announce munificent offers from the Government, the Empire Marketing Board, and the Royal Agricultural Society, amounting to $£ 101,000$ in all, of which $£ 85,000$ goes towards the sum required. The offers are conditional upon the remaining $£ 144,000$ being secured, but they will come as the greatest possible encouragement to the Committee charged with the task of securing to the University the magnificent opportunity presented to it by the munificent offer of the Rockefeller International Education Board.

The Right Hon. Walter Guinness, Minister of Agriculture and Fisheries, in communicating the Government's offer, writes as follows :

"The Board's generous benefaction recognises the position of the University as a great international institution of education and research; His Majesty's Government recognise equally that the University is a great national and a great imperial institution. Again, the particular purposes to which the benefaction is to be applied-primarily the advancement of agriculture and of the fundamental sciences on which agriculture depends-are such as must command the unhesitating support of His Majesty's Government in relation both to- this country and to the interest of the Empire overseas. . . . They believe that the highest national as well as imperial interests demand that the scheme agreed between the Universities and the International Education Board should be fully carried into effect. The Government offer a sum of $£ 50,000$ in respect of expenditure directly attributable to the School of Agriculture in the strictest sense.'

The Right Hon. L. S. Amery, Principal Secretary of State for Dominion Affairs and for the Colonies, in making an offer of $£ 50,000$ on behalf of the Empire Marketing Board, writes as follows :

"In a review which has now extended over more than two years, the Board have come to appreciate the great contribution which the University of Cambridge is already making to scientific agricultural research in the Empire at home and overseas. This offer, they are satisfied, holds out the promise of a development of high significance to every Empire country."

This substantial Government support, taken as an indication of the official attitude to research, will be most gratifying to scientific workers generally.

The Council of the Royal Agricultural Society has also made a generous offer of $£ 1000$. Cambridge men may be looked upon loyally to support the endeavours being made to raise the balance remaining, $£ 144,000$.

\section{Structure of the Great Barrier Reef. ${ }^{1}$}

THE results being accumulated by the Great 1 Barrier Reef Committee of Australia, the activities of which are directed by Prof. H. C. Richards, are highly creditable, but the task of closely investigating about $\frac{1}{4}$ million square miles of land, reef, and water is herculean. Investigations have to be governed by finance and the number of researchers available. The result here is a lack of system, which, however, has had its parallel in the investigations of the coasts of Great Britain and elsewhere.

Past earth movements may be studied in the topography of land surfaces, but we are glad to see that in addition a boring was put down near Cairns, a coral island within the barrier reef being selected. The same difficulties were met with as at Funafuti, insufficiently consolidated and irregular material making drilling difficult. The boring $\log$ showed coral material to $113 \mathrm{ft}$., ooze and mud to $213 \mathrm{ft}$, coral again to $241 \mathrm{ft}$., followed by ooze to $427 \mathrm{ft}$., and then glauconitic material with quartz sand to $600 \mathrm{ft}$. It is suggested that this is to be interpreted as indicating subsidence of $600 \mathrm{ft}$. , but we cannot accept this until we know what were the foraminifera obtained and have certain evidence that they exist only under quite shallow water conditions. The glauconite must have formed at the time of deposition, and the depth at which it occurred appears to us about the usual depth at which it commences to be formed. We trust that this core will be closely compared with the bottom deposits obtained by Dr. Yonge's expedition, which is working in the same region. Either this deposit was formed before the outer barrier grew up or is the filling up of the lagoon behind the same, as subsidence or other change of level took place, and we find difficulty in accepting either interpretation. A comparison with the deposits near Great Sandy Island at the south end of the Great Barrier Reef might perhaps be interesting.

1 “Reports of the Great Barrier Reef Committee," vol. 2. Pp. xvi+ $11 t+12$ plates. (Brisbane: A. J. Curnming, 1928.) $10 s$.
Mr. Stanley's study of the physiography of the Bowen district, $20^{\circ}-21^{\circ} \mathrm{S}$., is an important contribution to the interpretation of the formation of the Great Barrier Reef. Here there are lines of high islands running almost parallel to the mainland with the shelf-like surface of the Great Barrier Reef outside, $33.50 \mathrm{fm}$. deep. The chief of these islands is Whitsunday, which gives its name to a Passage on its landward side, a trench varying up to $50 \mathrm{fm}$. deep. The trend lines of the islands, of which seventeen are described, are much interrupted and the channels between the lines may be rather trough-like. The basal rocks are granites and palæozoic volcanies, figuring equally, and this is true of the coastal ranges. Many of the islands are deeply dissected and there are pronounced embayments, the cliffing being relatively small, this suggesting a long period of subærial erosion followed by submergence. Along some of the trend lines recent elevation is well marked, and, as it may be absent on their western sides, tilting is suggested. In various bays coral reefs are growing, but these would appear to be in process of formation, and not contemporaneous with, or of the same structure as, the barrier formations to seaward.

It is difficult to follow the author without an adequate chart of depths, in addition to his series of plans and drawings. He gives evidence to show that the relative resistance to weathering and to subsurface marine action cannot have acted as producing the systematic arrangement of the island lines. Hence warping is postulated, parallel to the present coast line, accompanied by the formation of huge parallel fault blocks, cross faulting limiting their extension and causing breaks. This took place subsequent to almost mature subærial dissection, and the barrier flat to the east is hence a drowned land and its even surface due to marine cutting down and filling in of inequalities. Daly's Glacial Control Theory, a former lowering of sea-level by $30-50 \mathrm{fm}$., is called in to explain its

No. 3085, VoL. 122] 